\title{
FOOD PREFERENCE OF Thyrinteina arnobia (STOLL, 1782) (LEPIDOPTERA: GEOMETRIDAE) ON NATIVE AND EXOTIC HOSTS
}

\author{
Camila Alexandre Cavalcante de Almeida $^{2 *}$ (e) Fernanda da Silva Gonçalves $^{3}{ }^{\circ}$, Matheus Barros \\ Rodrigues $^{4} \odot$,Jakeline Maria dos Santos $^{5} \odot$ and Mariana Oliveira Breda ${ }^{6}\left({ }^{\circ}\right.$
}

\footnotetext{
${ }^{1}$ Received on 11.04.2020 accepted for publication on 29.01.2021.

${ }^{2}$ Universidade Federal de Alagoas, Mestra em Proteção de Plantas, Rio Largo, AL - Brasil. E-mail: <camila.almeida@ceca.ufal.br>.

${ }^{3}$ Universidade Federal de Alagoas, Graduanda em Engenharia Florestal, Rio Largo, AL - Brasil. E-mail: <fernanda.gon6060@gmail.com>.

${ }^{4}$ Universidade Federal de Alagoas, Graduando em Engenharia Florestal, Rio Largo, AL - Brasil . E-mail: <matheusole19@gmail.com>.

${ }^{5}$ Universidade Federal de Alagoas, Doutora em Proteção de Plantas, Rio Largo, AL - Brasil. E-mail: <jackbilu@hotmail.com>.

${ }^{6}$ Universidade Federal de Alagoas, Laboratório de Entomologia Agrícola e Florestal, Rio Largo, AL - Brasil. E-mail: < mariana.breda@ ceca.ufal.br>.

*Corresponding author.
}

\begin{abstract}
One of the factors that may affect and limit the production in eucalypt plantations is the attack of defoliating insects. Among those, the brown eucalypt caterpillar, Thyrinteina arnobia (Stoll, 1782) (Lepidoptera: Geometridae), stands out for being the major defoliating pest of Eucalyptus spp. in Brazil. Thus, the present study aimed to investigate the food consumption of T. arnobia, in its native host, guava (Psidium guajava L.), and in the different E. urograndis clones (VE 41, I 144, TP 361 and VCC 865). To assess $T$. arnobia food consumption, choice and non-choice tests were carried out using the native and the exotic host, alone or in combination. In non-choice tests, it was observed a higher consumption for the VE 41 clone and the native host (guava). The food consumption evaluation in choice tests indicated no food preference of T. arnobia between guava and E. urograndis clones, with the exception for the TP 361 clone, which was significantly less consumed than guava. In choice tests between the different $E$. urograndis clones, the clone I 144 presented a tendency towards lower food preference, being consumed only after 48 hours. In addition, the leaf consumption was similar between the VE 41, I1 14 e VCC 865 clones. In choice tests using the E. urograndis clones in pairs, the VE 41 clone was more consumed while the I 144 clone was less consumed when compared to the TP 361 clone. The obtained results provide basic information for the indication of eucalypt clones, and the understanding of the interaction and ecological relationships, assisting in the development of Forest Integrated Pest Management (Forest IPM) programs for the control of T. arnobia.
\end{abstract}

Keywords: Eucalypt; Guava; Forest Integrated Pest Management.

\section{PREFERENCIA ALIMENTAR DE Thyrinteina arnobia (STOLL, 1782) (LEPIDOPTERA: GEOMETRIDAE) EM HOSPEDEIROS NATIVOS E EXÓTICOS}

RESUMO - Um dos fatores que podem afetar e limitar a produção nas lavouras de eucalipto é o ataque de insetos desfolhadores. Dentre essas, a lagarta marrom do eucalipto, Thyrinteina arnobia (Stoll, 1782) (Lepidoptera: Geometridae), destaca-se por ser a principal praga desfolhadora de Eucalyptus spp. no Brasil. Assim, o presente estudo teve como objetivo investigar o consumo alimentar de T. arnobia, em seu hospedeiro nativo, a goiaba (Psidium guajava L.) e em diferentes clones de E. urograndis (VE 41, I 144, TP 361 e VCC 865). Para a avaliação do consumo alimentar de T. arnobia, foram realizados testes de escolha e não escolha utilizando o hospedeiro nativo e o exótico, isoladamente ou em combinação. Nos testes sem chance de escolha, foi observado maior consumo para o clone VE 41 e para o hospedeiro nativo goiaba. A avaliação do consumo alimentar em testes de escolha não indicou preferência alimentar de T. arnobia entre a goiaba e os clones de $\boldsymbol{E}$. urograndis, com exceção do clone TP 361, que foi significativamente menos consumido do que a goiaba. Em testes de escolha entre os diferentes clones de $\boldsymbol{E}$. urograndis, o clone I 144 apresentou tendência a menor preferência alimentar, sendo consumido somente após 48 horas. Além disso, o consumo de folhas foi semelhante entre os clones VE 41, I1 14 e VCC 865. Em testes de escolha usando os clones de E. urograndis em pares, o clone VE 41 foi mais consumido enquanto o clone I 144 foi menos consumido quando comparado ao clone TP 361. Os resultados obtidos fornecem informações básicas para a indicação de clones de eucalipto

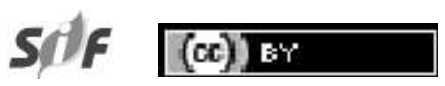

Revista Árvore 2021;45:e4511 http://dx.doi.org/10.1590/1806-908820210000011 


\begin{abstract}
e entendimento da interação e relações ecológicas, auxiliando no desenvolvimento de programas de Manejo Integrado de Pragas Florestais (MIP Florestal) para o controle de T. arnobia.
\end{abstract}

Palavras-Chave: Eucalipto; Goiaba; Manejo Integrado de Pragas Florestais.

\section{INTRODUCTION}

For purposes of forestry genetic improvement, the genotypic features of each genetic material may directly affect the insect-plant interaction. Thus, it is essential to identify and characterize possible resistance factors, contributing to the development of appropriate and efficient pest management strategies (Jesus et al., 2015).

Among the insects native to Brazil, Thyrinteina arnobia stands out for being found all over the national territory and has migrated from its native hosts, such as guava (Psidium guajava L.), to the exotic host Eucalyptus spp., becoming the main defoliator on eucalypt crops in the country, requiring the constant use of pest control techniques (Barreto and Mojena, 2014). Therefore, several management tactics are being developed to mitigate the yield losses caused by T. arnobia, including the selection of less susceptible species in the genus Eucalyptus, as well as the search for resistant genotypes or clones.

According to Boiça Júnior et al. (2013), plant resistance is a feature depending on environmental and genetic factors, and for that, different genetic materials, such as species, hybrids and/or clones of Eucalyptus spp. may show variations in susceptibility to biological agents, including defoliating insects, such as $T$. arnobia. Thus, the search for resistance features is essential, since the presence of morphological or chemical stimuli can affect herbivory and depress the consumption and food preference of insects, keeping the population density of the pests below the level of economic damage, having no or low adverse effect on the environment (Seifi et al., 2013). Nevertheless, studies related to the interaction of native and exotic host species and the food consumption of T. arnobia, in the search for the characterization of non-preference resistance are still rare. Jesus et al. (2015) in tests using species/genotypes of Eucalyptus spp., found results that consider Eucalyptus dunnii and the hybrid Corymbia citriodora x Corymbia torelliana presented antibiosis and/or antixenosis for T. arnobia. Similarly, clone C10 (C. citriodora x C. torelliana), proved to be less preferred by $T$. arnobia, corroborating that T. arnobia exhibits a distinction between the genetic materials offered.

Thus, the present study aimed to investigate the food consumption of T. arnobia on its native host guava and on different E. urograndis clones (VE 41, I 144, TP 361 and VCC 865) in order to contribute to the development of Integrated Forest Pest Management programs (Forest IPM).

\section{MATERIAL AND METHODS}

The research was conducted at the Laboratory of Agricultural and Forestry Entomology (LEAF) of the Engineering and Agricultural Sciences Campus, Federal University of Alagoas (CECA/UFAL) and at Embrapa Coastal Tablelands.

\subsection{T. arnobia field collection}

T. arnobia was obtained through manual collections in E. urograndis crops, variety 1407 and 224, at Albuquerque Farm, municipality of Atalaia, Alagoas state, $9^{\circ} 30^{\prime} 27^{\prime}$ 'S and $36^{\circ} 1^{\prime} 24^{\prime}$ ' W. The biological forms, such as eggs, caterpillars, pupae and/or adults were collected manually or with the aid of an entomological net and then transported to the Laboratory of Agricultural and Forestry Entomology (LEAF).

\subsection{T. arnobia rearing}

T. arnobia eggs were immersed in copper sulfate solution (CuSO4) for 10 seconds, then washed in distilled water in order to avoid contamination and placed in Petri dishes, with moistened filter paper, until the eggs hatch. After hatching, the caterpillars were placed in plastic buckets of 20L, with two side openings and a lid with holes covered by voile fabric. For feeding, leaves of E. urograndis or guava were offered, in branches, placed in $500 \mathrm{ml}$ glass bottles with water, until the loss of turgor, when they were replaced by new branches. Pupae were sexed and coupled in $10 \times 20 \mathrm{~cm}$ PVC tube cages, internally

Revista Árvore 2021;45:e4511 
lined with sulfite paper, for adult emergence and oviposition. The adults were daily fed with a $10 \%$ honey solution. Eggs were daily collected.

\subsection{T. arnobia food consumption bioassays}

For the food consumption evaluation of $T$. arnobia on E. urograndis clones (TP 361, VCC 865, I1 44 and VE 41) and/or guava, T. arnobia caterpillars with approximately $2 \mathrm{~cm}$ (4th instar) (Holtz et al., 2003a), were used, fed with E. urograndis variety 1407 and 224.

Guava leaves were collected from trees belonging to the Campus and the different E. urograndis clones (TP 361, VCC 865, I1 44 and VE 41) were collected in the experimental clonal forest stand of the Engineering and Agricultural Sciences Campus (CECA). Then, the samples were labelled and taken to the Agricultural and Forestry Entomology Laboratory (LEAF), washed in running water and cut into $4 \mathrm{~cm}$ diameter discs $\left(\approx 1378 \mathrm{~mm}^{2}\right)$.

To determine the consumed area, the host leaves were previously drawn on bond paper and at each evaluation period, the consumed area was marked in its respective outline, with different colours for each period. Thereafter, T. arnobia food consumption was determined using the Bioscentific Lad ADC-AM-3000 leaf area meter.

\subsubsection{Food consumption of $T$. arnobia on $E$. urograndis clones and guava in non-choice tests.}

The leaf discs of E. urograndis clones (VE 41, I 144, TP 361, VCC 865) and guava were individualized in arenas of $6.0 \times 5.0 \mathrm{~cm}$ plastic pots, lined with filter paper and moistened with distilled water. Subsequently, one T. arnobia caterpillar was released in each arena and the leaf consumption was evaluated after 24 hours and 48 hours.

The experimental design was completely randomized, with 10 repetitions and 05 treatments, 4 clones of eucalypt (TP 361, VCC 865, I1 44 and VE 41) and 1 of guava. The data obtained were subjected to analysis of variance (ANOVA) and the means compared by the Tukey test $(\mathrm{P} \leq 0.05)$, using the statistical package of the SAS version 9.0 program (SAS Institute, 2011). Graphics were created using the SigmaPlot Software version 11.0 (Systat software, 2006).
2.3.2 Food consumption of $T$. arnobia in free choice
tests using paired $E$. urograndis clones with guava.

For the evaluation of T. arnobia food consumption in free choice tests with E. urograndis clones (TP 361, VCC 865, I1 44 and VE 41) and guava, plastic pots $(26 \times 16 \times 4 \mathrm{~cm})$ with an orifice in the lid, covered with voile fabric, and lined with polyethylene foam, moistened with distilled water and covered with filter paper, were used as arenas. In each arena, the leaves of the different hosts were placed in pairs (E. urograndis clone $\mathrm{x}$ guava), equidistant from the center and from each other. One T. arnobia caterpillar was released in the center of the arena and after 24 and 48 hours, the consumed area of each disc was evaluated.

The experimental design was completely randomized, with five treatments (VE41 × Guava; I144 × Guava; TP361 × Guava; and VCC865 × Guava) and five repetitions for each treatment. The data were submitted to the Chi-squared test of Independence $(\mathrm{P} \leq$ $0.05)$, using the statistical package of the SAS version 9.0 program (SAS Institute, 2011). The graphics were created using the SigmaPlot Software version 11.0 (Systat software, 2006).

\subsubsection{Food consumption of T. arnobia in free choice tests among $E$. urograndis clones.}

For the evaluation of $T$. arnobia food consumption in free choice tests among $E$. urograndis clones, plastic pots $(26 \times 16 \times 4 \mathrm{~cm})$ with an orifice in the lid, covered with voile fabric, and lined with polyethylene foam, moistened with distilled water and covered with filter paper, were used as arenas. In each arena, the four clones (TP 361, VCC 865, I1 44 and VE 41) were arranged concomitantly, in a circle, equidistant from the centre and from each other. One T. arnobia caterpillar was released in the centre of the arena and after $30 \mathrm{~min}, 2,4,6,24$ and 48 hours, the leaf consumption was assessed.

The experimental design was completely randomized, with four treatments (VE 41, I 144, TP 361 and VCC 865) and 10 repetitions. The data were submitted to analysis of variance (ANOVA) and the means compared by the Tukey test $(\mathrm{P} \leq 0.05)$, using the statistical package of the SAS version 9.0 program (SAS Institute, 2011). Graphics were created using the SigmaPlot Software version 11.0 (Systat software, 2006).

\section{Revista Árvore 2021;45:e4511}


2.3.4 Food consumption of T. arnobia in free choice tests using paired $E$. urograndis clones.

For the evaluation of T. arnobia food consumption in free choice tests using paired E. urograndis clone plastic pots $(26 \times 16 \times 4 \mathrm{~cm})$ with an orifice in the lid, covered with voile fabric, and lined with polyethylene foam, moistened with distilled water and covered with filter paper, were used as arenas. In each arena, the leaves of the different clones were placed in pairs, equidistant from the center and from each other. One T. arnobia caterpillar was released and after 24 and 48 hours, the leaf consumption was evaluated.

The experimental design was completely randomized, with five replications and six treatments, resulting from the following pairings: TP $361 \times \mathrm{VE}$ 41; TP $361 \times$ I 144; TP $361 \times$ VCC $865 ;$ VE $41 \times$ I 144; VE $41 \times$ VCC 865; and VCC $865 \times$ I 144 . The data were submitted to the Chi-squared test of Independence $(\mathrm{P} \leq 0.05)$, using the statistical package of the SAS program version 9.0 (SAS Institute, 2011). Graphics were created using the SigmaPlot Software version 11.0 (Systat software, 2006).

\section{RESULTS}

\subsection{Food consumption of T. arnobia on $E$. urograndis} clones and guava in non-choice tests.

Data from food consumption of T. arnobia on $E$. urograndis clones and guava in non-choice tests, revealed significant differences between the evaluated treatments after $24 \mathrm{~h}(\mathrm{~F}=9.25 ; \mathrm{P}<0.0001)$ and $48 \mathrm{~h}(\mathrm{~F}$ $=10.33 ; \mathrm{P}<0.0001)$, following the same pattern of leaf consumption on both periods.

It was found that all treatments were consumed, however, greater consumption of leaf area was observed for the native host guava, with an average leaf consumption area of $480.6 \pm 89.52 \mathrm{~mm}^{2}$ and $841.1 \pm 132.7 \mathrm{~mm}^{2}$, followed by the VE 41 clone with $455.6 \pm 94.2 \mathrm{~mm}^{2}$ and $560.1 \pm 108.5 \mathrm{~mm}^{2}$ after 24 and 48 hours, respectively, significantly differing from the other treatments (Figure 1).

The TP 361, I 144 and VCC 865 clones presented leaf consumption area of $143.8 \pm 23.17 \mathrm{~mm}^{2}$ and 273.5 $\pm 56.3 \mathrm{~mm}^{2} ; 166.8 \pm 28.03 \mathrm{~mm}^{2}$ and $296.8 \pm 48.5 \mathrm{~mm}^{2}$ ; and $93.3 \pm 15.33 \mathrm{~mm}^{2}$ and $165.8 \pm 33.5 \mathrm{~mm}^{2}$ after 24 and 48 hours, respectively, which did not differ significantly among them.

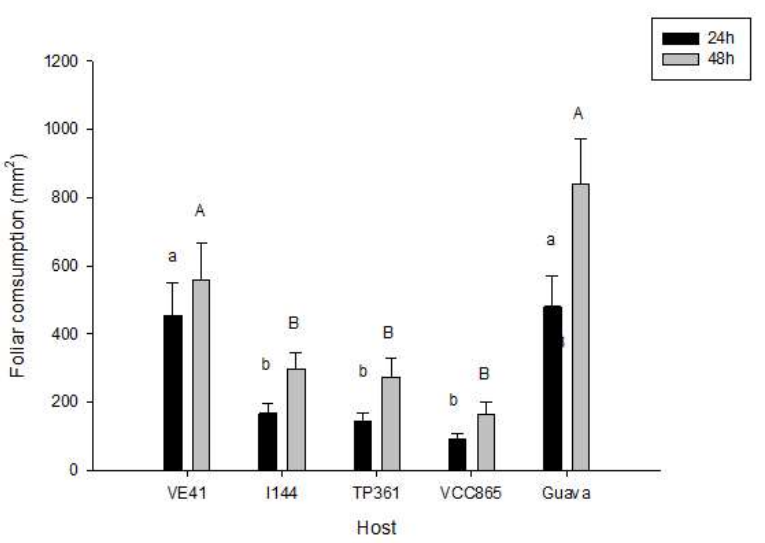

Figure 1 - Foliar consumption $\left(\mathrm{mm}^{2}\right)$ of Thyrinteina arnobia (Stoll, 1782) (Lepidoptera: Geometridae) in non-choice tests using Eucalyptus urograndis clones (VE41, I144, TP361 and VCC865) and guava (Psidium guajava L.) after 24 and 48 hours.

Figura 1 -Consumo foliar $\left(\mathrm{mm}^{2}\right)$ de Thyrinteina arnobia (Stoll, 1782) (Lepidoptera: Geometridae) sem chance de escolha em diferentes clones de Eucalyptus urograndis (VE41, I144, TP361 e VCC865) e goiaba (Psidium guajava L.) após 24 e 48 horas.

\subsection{Food consumption of T. arnobia in free choice} tests using paired $E$. urograndis clones with guava.

The results obtained for the food consumption of T. arnobia on paired E. urograndis clones with guava (VE 41 x Guava; VCC 865 x Guava; I1 44 x Guava) showed similar consumption for the hosts, after $24 \mathrm{~h}$ and $48 \mathrm{~h}$.

Among the evaluated pairings, it was only possible to observe greater consumption of the native guava host $\left(213.1 \pm 107 \mathrm{~mm}^{2}\right.$ and $\left.252.4 \pm 121 \mathrm{~mm}^{2}\right)$ when paired with the TP361 clone $\left(47.2 \pm 47 \mathrm{~mm}^{2}\right.$ and 47.2 $\pm 47 \mathrm{~mm}^{2}$ ) after 24 and $48 \mathrm{~h}$, respectively (Figure 2).

\subsection{Food consumption of T. arnobia in free choice tests among $E$. urograndis clones.}

Regarding the food consumption in free choice tests among the E. urograndis clones, it was observed that after $2 \mathrm{~h}$ of evaluation, only the VE 41 (4.2 \pm $\left.4.2 \mathrm{~mm}^{2}\right)$ and TP $361\left(7.0 \pm 7.0 \mathrm{~mm}^{2}\right)$ clones were consumed, despite not differing from the other unconsumed clones $(\mathrm{F}=1.0 ; \mathrm{P}=0.40)$.

After $4 \mathrm{~h}(\mathrm{~F}=0.94 ; \mathrm{P}=0.42), 6 \mathrm{~h}(\mathrm{~F}=0.64 ; \mathrm{P}$ $=0.59)$ and $24 \mathrm{~h}(\mathrm{~F}=2.43 ; \mathrm{P}=0.038)$ of evaluation, VE 41, TP 361 and VCC 865 clones were consumed by $T$. arnobia, which did not differ among them. Nevertheless, statistical differences were determined after $24 \mathrm{~h}$, when the consumption of the VE41 clone 



Foliar comsuption $\left(\mathrm{mm}^{2}\right)$ on different host

Figure 2 - Foliar consumption $\left(\mathrm{mm}^{2}\right)$ of Thyrinteina arnobia (Stoll, 1782) (Lepidoptera: Geometridae) in free choice tests using pairing Eucalyptus urograndis clones (VE41, I144, TP361 and VCC865) and guava (Psidium guajava L.) after 24 and 48 hours.

Figura 2 - Consumo foliar $\left(\mathrm{mm}^{2}\right)$ de Thyrinteina arnobia Stoll, 1782 (Lepidoptera: Geometridae) com chance de escolha em diferentes clones de Eucalyptus urograndis (VE41, VCC865, TP361 e I144) e goiaba (Psidium guajava L.) após 24 h e 48h de avaliação.

$\left(56.1 \pm 25.5 \mathrm{~mm}^{2}\right)$ differed from the unconsumed I144 clone $\left(0.0 \pm 0.0 \mathrm{~mm}^{2}\right)$.

In general, I 144 clone presented a lower food preference from $T$. arnobia, being consumed only after 48 hours of evaluation. In spite of this, statistical differences were not identified for this evaluation period between any of the tested clones, with average values of area consumed of $31.3 \pm 21.8 \mathrm{~mm}^{2}$ for I 144 ; $37.4 \pm 18.02 \mathrm{~mm}^{2}$ for TP $361 ; 90.7 \pm 52.1 \mathrm{~mm}^{2}$ for VE 41 ; and $94.0 \pm 28.0 \mathrm{~mm}^{2}$ for $\mathrm{VCC} 865(\mathrm{~F}=1.05 ; \mathrm{P}=$ 0.38 ) (Figure 3).

\section{Revista Árvore 2021;45:e4511}




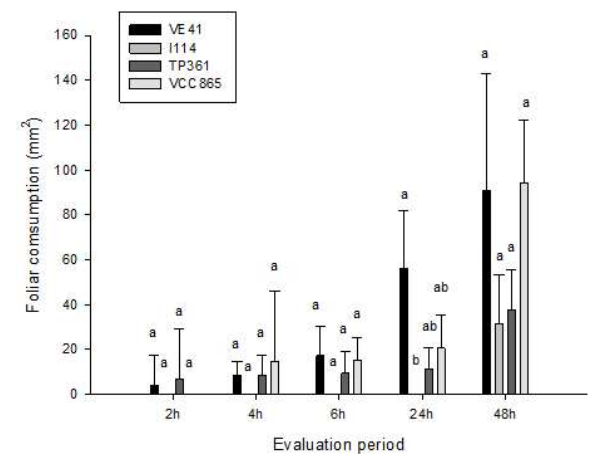

Figure 3 - Foliar consumption $\left(\mathrm{mm}^{2}\right)$ of Thyrinteina arnobia (Stoll, 1782) (Lepidoptera: Geometridae) in free choice tests using Eucalyptus urograndis clones (VE41, I144, TP361 and VCC865) after 2, 4, 6, 24 and 48 hours.

Figura 3 - Consumo foliar $\left(\mathrm{mm}^{2}\right)$ de Thyrinteina arnobia (Lepidoptera: Geometridae) em diferentes clones de Eucalyptus urograndis (VE41, I114, TP361, VCC865) após 2,4,6,24 e 48 horas de avaliação.

3.4 The food consumption of $T$. arnobia in free choice tests using paired $E$. urograndis clones.

For the food consumption in free choice tests using paired $E$. urograndis clones, a significant difference was observed in both evaluation periods ( 24 and 48h), for the pairing between I $144 \times$ TP 361 clones, showing lower consumption of I 144 clone, with average values of $7.8 \pm 10.7 \mathrm{~mm}^{2}$ for I 144 and $94.4 \pm 89.4 \mathrm{~mm}^{2}$ for TP 361, after $24 \mathrm{~h}(\mathrm{~F}=69.52$; $\mathrm{P}$ $=0.00012)$; as well as $98 \pm 44.7 \mathrm{~mm}^{2}$ for I 144 and $161.8 \pm 85.6 \mathrm{~mm}^{2}$ for TP 361 after $48 \mathrm{~h}(\mathrm{~F}=10.21 ; \mathrm{P}$ $=0.004)$.

Likewise, significant differences were observed

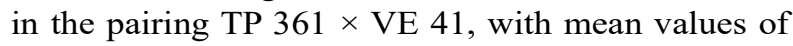
leaf area consumed of $5.2 \pm 6.9 \mathrm{~mm}^{2}$ for TP 361 and $40.2 \pm 34.9 \mathrm{~mm}^{2}$ for VE 41 , after $24 \mathrm{~h}(\mathrm{~F}=25.10 ; \mathrm{P}=$ $0.008)$; as well as $10.0 \pm 13.4 \mathrm{~mm}^{2}$ for TP 361 and 73.4 $\pm 66.3 \mathrm{~mm}^{2}$ for $\mathrm{VE} 41$ after $48 \mathrm{~h}(\mathrm{~F}=23.28 ; \mathrm{P}=0.009)$ (Figure 4).

For the other pairings, no significant differences were observed in any of the evaluated periods.

\section{DISCUSSION}

According to the results, it is possible to observe significant differences in the food consumption of T. arnobia among native and exotic hosts as well as among the tested genetic materials (clones).

The VE 41 clone and the native host guava were more consumed than the other genetic materials tested in non-choice food consumption tests. This fact suggests that the least consumed clones (I 144, VCC 865 and TP 361) may possibly present chemical, physical or morphological stimuli able to reduce $T$. arnobia feeding (Lima et al., 2018).

It is important to note that, although the native host guava has been more consumed than the I 144, VCC 865 and TP 361 clones, when offered in nonchoice tests, the native host was not always the most preferred, when $T$. arnobia had a chance to choose. These results suggest that $T$. arnobia may present a similar attraction to the stimuli emitted by both the native host and the tested genotypes of the exotic host, with the exception of TP 361 clone. This fact is quite notable, since the hybrid E. urograndis was developed in Brazil in the mid-70s (Faria et al., 2013), revealing that in a relatively short period of time, T. arnobia no longer distinguishes between its native and exotic hosts. However, in spite of not presenting remarkable preference between the native and exotic hosts, there is evidence in the literature that suggests differences in T. arnobia development (Marinho et al., 2008; Holtz et al., 2003b; Santos et al., 2000).

Holtz et al. (2003c) reported that $T$. arnobia had a higher intrinsic population growth rate $(\mathrm{rm})$ in E. cloesiana than in its native host guava. However, Santos et al., (2000) assessing the development of T. arnobia in E. urophylla and guava, demonstrated a better performance in the native host, with $5 \%$ of larval mortality in guava against $46.5 \%$ in E. urophylla. In general, even though there is no consensus among the authors, these facts point to an adaptation of $T$. arnobia to the exotic host.

According to West and Cunnengham (2002), outbreaks of T. arnobia populations in forest stands of Eucalyptus spp. are often considered larger than in the native host guava crops, indicating that this fact may be due to the production method and not only to the genetic features of the hosts, as the forest plantations of Eucalyptus spp.

These are crops commonly presented in extensive and contiguous clonal monoculture, favouring the incidence of pests, demonstrating that the preference for a host may depend on many factors, such as the quality and amount of available food resources (West and Cunnengham, 2002). 

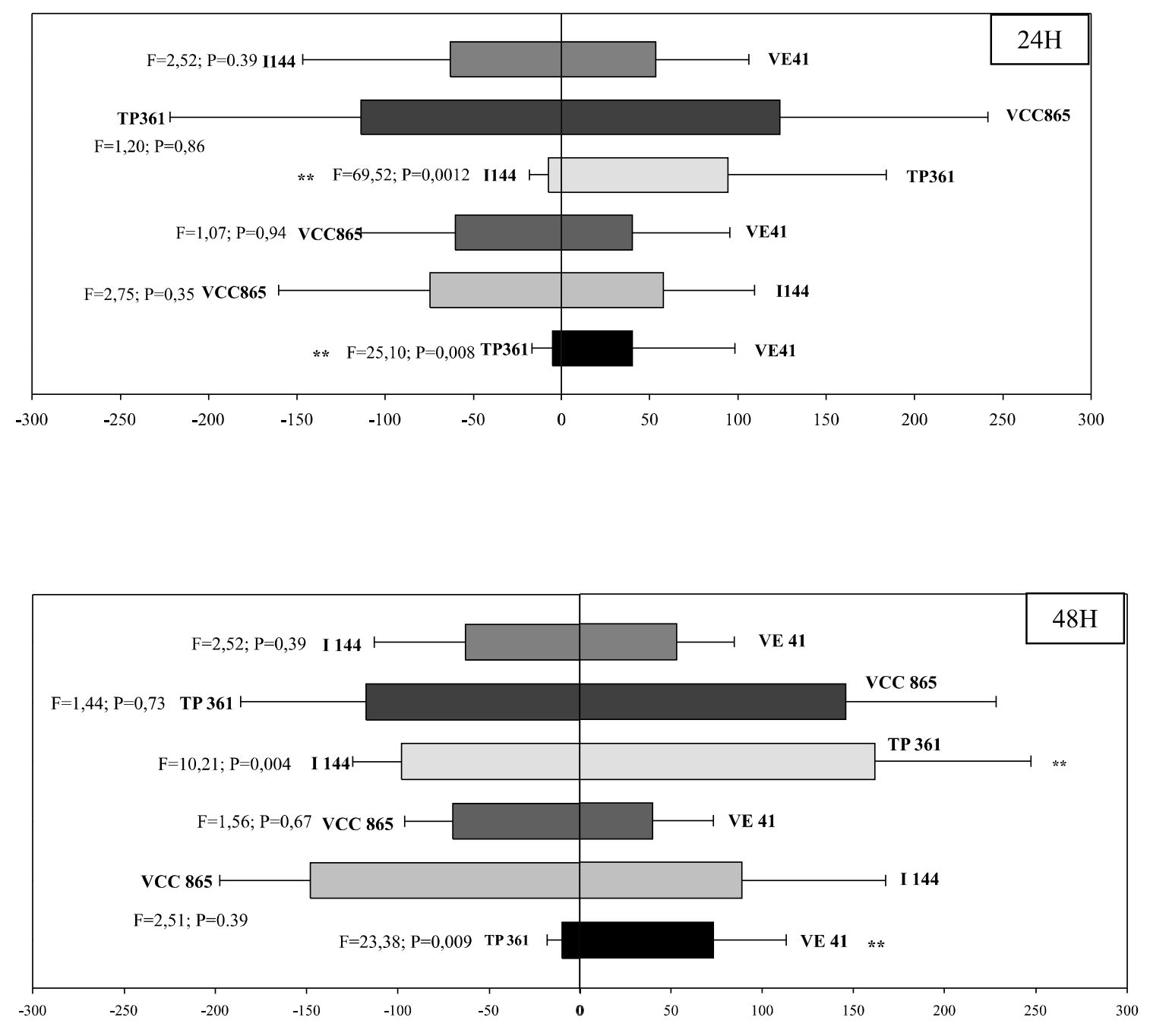

Foliar consumption $\left(\mathrm{mm}^{2}\right)$ on Eucalyptus urograndis clones

Figure 4 - Foliar consumption $\left(\mathrm{mm}^{2}\right)$ of Thyrinteina arnobia (Stoll, 1782) (Lepidoptera: Geometridae) in free choice tests using pairing Eucalyptus urograndis clones (VE41, I144, TP361 and VCC865) after 24 and 48 hours.

Figura 4 - Consumo foliar $\left(\mathrm{mm}^{2}\right)$ de Thyrinteina arnobia Stoll, 1782 (Lepidoptera: Geometridae) com chance de escolha em diferentes clones de Eucalyptus urograndis (VE41, I114, TP361, VCC865) em pareamento após 24 e 48 horas de avaliação.

Among the possible causes for the succession of T. arnobia population outbreaks in Eucalyptus spp., Marinho et al. (2008) consider that the exotic host has not yet developed defensive mechanisms, which would have already happened with the native host, in co-evolution processes, this is because eucalyptus plants produce more protease inhibitors than guava, but are more attacked by caterpillars of the genus Thyrinteina that possibly adapted for the protection of those plants by increasing the production of digestive enzymes.

Futuyama (2008) approaches that adaptations to introduced exotic genetic materials have been gradually occurring in several species of insects, increasing the host range and favouring the change and maintenance of the population level between native and exotic hosts, thus ensuring the survival of these individuals in the field. 
The lower consumption observed for the clone 144 in the present study is substantiated on the fact that in the state of Alagoas, Brazil, the same $E$. urograndis clone has shown a higher productivity when compared to the others, being the most used clone for forest stands implantations in the region. This higher productivity may be related to lower attack by pest insects, including $T$. arnobia, which defoliates Eucalyptus spp. directly affecting growth rates and in case of continuous attacks may cause the death of its host (Pereira 2007; Moreira 2013).

Nevertheless, when the E. urograndis clones were offered in pairs, the I 144 clone was only significantly less preferred when compared to clone TP 361, indicating that when there is few options of choice, T. arnobia tends to make low distinction between the offered materials.

When it comes to food preference, the insect responses may vary according to the stimuli coming from the host plant, being of chemical (allelochemical), physical (colour) or morphological nature (hairiness, texture, hardness, structure dimension, among others). For Eucalyptus spp., physical-chemical features, in addition to the presence of secondary compounds, such as tannins, phenols, fats and essential oils, can provide phagostimulating or deterrent properties, influencing the herbivory process, showing a direct influence on host preference (Ohmart et al., 1985; Lara, 1991; Ohmart and Edwards, 1991).

The results of although it was not possible to affirm the existence of non-preference resistance among the different clones of E. urograndis (VE 41, I1 44, TP 361, VCC 865) and the native host guava for T. arnobia, the results of the present study suggest a higher consumption for the VE 41 clone and guava, as well as a low preference for the I1 44 clone.

In general, the investigation of the interactions of native and exotic hosts and T. arnobia is of fundamental importance for a better understanding of ecological relationships, assisting in the development, planning and use of appropriate methods for Forest Integrated Pest Management programs (Forest IPM).

\section{CONCLUSIONS}

There are differences in the food consumption of $T$. arnobia between its native and exotic hosts, in which the VE 41 clone and the native host guava were more consumed, when compared to the other tested genetic material. The TP 361 clone was less preferred when offered paired to the native guava host and the I 144 clone presented less food preference, when the genetic materials were offered together. The results obtained provide basic information for the indication of eucalypt clones and understanding of the interaction and ecological relationships, assisting in the development of Forest Integrated Pest Management (Forest IPM) programs for the control of T. arnobia.

\section{AUTHOR CONTRIBUTIONS}

Almeida, C. A. C. and Breda, M. O. was responsible for the conception and design of the work, data collection, data analysis and interpretation, drafting the article, revision and final approval of the version to be published. Santos, J. M., Gonçalves, F. S. and Rodrigues, M. B. was responsible for the data collection.

\section{REFERENCES}

Barreto MR, Mojena PA. La Aparición de Thyrinteina arnobia (Stoll) (Lepidoptera: Geometridae) de Eucalyptus y su Depredación por Zelus armillatus (Lepeletier y Serville) (Reduviidae: Harpactorinae). EntomoBrasilis. 2014;7(1):69-71. doi: $10.12741 /$ ebrasilis.v7i1.371.

Boiça Júnior AL, Souza BHS, Lopes GS, Costa EN, Moraes RFO, Eduardo WI. Atualidades em resistência de plantas a insetos. In: Busoli AC, Alencar JRCC, Fraga DF, Souza LA, Souza BHS, Grigolli JFJ, Editores. Tópicos em entomologia agrícola - VI. Jaboticabal: Maria de Lourdes Brandel; 2013. v.6. p. 207-224.

Faria JR, Silva JF, Neris KP, Rodrigues LFL, Costa SM, Sardinha LE, et al. Desenvolvimento de Eucaliptus urograndis no município de CorumbáGO. Ensaios e Ciência: Ciências Biológicas, Agrárias e da Saúde. 2013;17(2):9-27. doi: 10.17921/1415-6938.2013v17n2p\%25p.

Futuyama DJ. Some current approaches to the evolution of plant-herbivore interactions. Plant Species Biology. 2008;15(1):1-9. doi: 10.1046/j.1442-1984.2000.00029.x 
Holtz AM, Oliveira HG, Pallini A, Marinho JS, Zanuncio JC, Oliveira CL. Adaptação de Thyrinteina arnobia em novo hospedeiro e defesa induzida por herbívoros em eucalipto. Pesquisa Agropecuária Brasileira. 2003b; 38:453-458. doi: 10.1590/S0100204X2003000400002.

Holtz AM, Oliveira HG, Pallini A, Venzon M, Zanuncio JC, Oliveira CL, et al. Desempenho de Thyrinteina arnobia Stoll (Lepidoptera: Geometridae) em Eucalipto e Goiaba: o Hospedeiro Nativo Não é um Bom Hospedeiro?. Neotropical Entomology. 2003a;32(3):427-431. doi: 10.1590/ S1519-566X2003000300007.

Holtz AM, Zanuncio JC, Oliveira HG, Pallini A, Marinho JS, Oliveira CL, Pinon TBM. Aspectos biológicos de Thyrinteina arnobia (Lep.:

Geometriadae) provenientes de lagartas criadas em folhas de Eucalyptus cloeziana ou de Psidium guajava sob condições de campo. Revista Árvore. 2003c;27(6): 897-901. doi: 10.1590/S010067622003000600016 .

Jesus FG, Nogueira L, Boiça Júnior AL, Ribeiro ZA, Araújo MS, Zanuncio JC. Resistance of Eucalyptus spp. Genotypes to eucalyptus brown looper Thyrinteina arnobia (Lepidoptera: Geometridae). Australian Journal of Crop Science. 2015;9(11):1016-21.

Lara FM. Princípios de resistência de plantas a insetos. 2 th ed. São Paulo: Ícone; 1991.

Lima PR, Malavasi UC, Dranski JAL, Malavasi MM, Borsoi A, Ecco M. Estímulos químico e mecânico na rustificação de mudas de eucalipto. Rev. Ceres. 2018;65( 5 ): 424-432.

Ohmart CP. Effects of food quality, particularly nitrogen concentrations, of Eucalyptus blakelyi foliage on the growth of Paropsis atomaria larvae (Coleoptera: Chrysomelidae). Oecologia. 1985;65(4):543-549.

Ohmart CP, Edwards PB. Insect herbivory on eucalyptus. Annual Review of Entomology. 1991;36:637-657. doi: 10.1146/annurev. en.36.010191.003225

Marinho JS, Oliveira MGA, Guedes RNC, Pallini A, Oliveira CL. Inibidores de proteases de hospedeiros nativos e exóticos e sua ação em intestinos de lagartas de Thyrinteina leucoceraea. Revista Árvore. 2008;32(6):1125-1132. doi: 10.1590/S010067622008000600018

Moreira JA, Neppe T, Paiva MM, Deobald AM, Batista-Pereira LG, Paixão MW, Corrêa AG. Studies towards the Identification of the Sex Pheromone of Thyrinteina arnobia. J. Braz. Chem. Soc. 2013;24(12):1933-1941. doi: 10.5935/01035053.20130241 .

Pereira LGB. A Lagarta-Parda, Thyrinteina arnobia, principal lepidóptero desfolhador da cultura do eucalipto. Fundação Centro Tecnológico de MinasCETEC/MG. 28p, 2007.

Santos GP, Zanuncio TV, Zanuncio JC.

Desenvolvimento de Thyrinteina arnobia Stoll (Lepidoptera: Geometridae) em folhas de Eucalyptus urophylla e Psidium guajava. Anais da Sociedade Entomológica do Brasil. 2000;29(1):13-22. doi: 10.1590/S0301-80592000000100002

Sas Institute. SAS/STAT User'sguide, version 9.0, TS level 2MO. SAS Institute; 2011.

Seifi A, Visser RGF, Yuling B. How to effectively deploy plant resistances to pests and pathogens in crop breeding. Euphytica. 2013;190:321-334. doi: 10.1007/s10681-012-0823-9.

Systat Software. SigmaPlot for Windows Version 12.0. San Jose: Systat Software Inc., 2006.

West SA, Cunnengham JP. A general model for host plant selection in phytophagous insects. Journal of Theoretical Biology. 2002;214(3):499-513. doi: 10.1006/jtbi.2001.2475. 